\title{
a Canadian Commentary on Constructive EXPROPRIATION LAW UNDER NAFTA ARTICLE 1110
}

\author{
RAYMOND E. YOUNG*
}

By virfue of the Constitution Act, 1982. Canada has established that some rights and freedoms are bejond the reach of govermmen. However. the protection of property, especially withregard to the guarantecing of compensation if property is taken by the sfate, has not been elevated to this same level of constitutional protection. This article examines regulatory lakings claims under Article 1110 of the North American Frec Trade Agreement and provides an exposition of the law insofar as it has developed in the NAFTA context. It begins with a survey of constructive takings in international and domestic. U.S. law and concludes by highlighing the obvious differences between the protection afforded to foreign NAFTA investors in Canada and domestic owners of property when properny is raken.
Selon la Loi constilutionnelle de 1982. Ie Camada a itabli que certains droits at libertes som hors de la portie du gouvernemem. C'ependant, la protection de la propricifi, surtow en ce gui concerme la garantice d'indenmisation en cas de prise par l'État, $n$ a pras été portée au mime niveau de protection constitulionnelle. Cet article examine les prises effectuées en vertu de larticle 1110 de $/$ Accord de libre-échange nordamericain et donne un operç de la loi telle qu'elle a été développée dans le contexte de I A LENA. L. 'urticle commence par un sondage des prises consuructives en vertir des tois imernationales of nationales des ÉtalsUnis ef conchu en somlignam les differences évidenes entre la protection accordic anx investisseurs itrangers de I AL.ÉNA an Camada er les proprickaires domestigues en cas de prise de proprieité.

\section{TABLE OF CONTENTS}

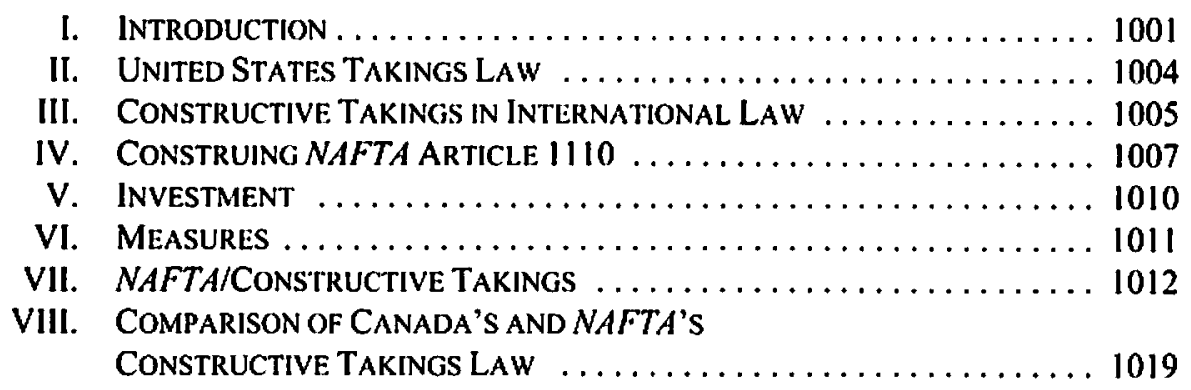

\section{INTRODUCTION}

In 1960 Viscount Simmonds' introduced into Anglo-Canadian law Holmes J.'s oft-cited observation that

[t]he general rule at least is, that while property may be regulated to a certain extent, if regulation gocs too far, it will be recognized as a taking. 2

Partner, Lidstone Young Anderson, Vancouver, Britisl Columbia. This article was made possible by a Canada-United States Senior Fulbright Award which allowed me to spend a term at Georgia State University (Allanta) lecturing and doing the rescarch. I am indebted to Prolessor Julian Juergensmeyer for all his support and assistance.

1 Belfast Corpn. v. O.D. Cars Lid., [1960] A.C. 490 at 519 (H.L.) [Belfast].

: Pennsylwania Coal Co. v. Mahon, 260 U.S. 393 at 415 (1922) [Pennsivivania Coal]. 
The development of American regulatory takings law has proceeded on the basis of the implementation of a self-executing constitutional right, ${ }^{3}$ and has consequently enjoyed a higher judicial and popular profile than the common law concept of constructive expropriation.

The impact of regulation on property in Canadian domestic law is defined not by any constitutional protection or by international treaty, but rather by the principle of Parliamentary sovereignty. Not only may property in Canada be taken by government, but an owner can also be deprived of property without any right to compensation. ${ }^{4}$ Where Parliamentary sovereignty is the rule, no law is beyond the reach of Parliament. ${ }^{5}$ While Canada has by virtue of the Constizution Act, 1982, ${ }^{6}$ raised certain rights and freedoms above and beyond the reach of Parliaments, the protection of property ownership - in particular, the guarantecing of compensation if property is taken by the state - is not so enshrined.?

Despite the obvious authority of the Canadian Parliament and legislatures to take property without compensation, they do not do so. When Parliament formally takes, it always makes statulory provision for payment and for the independent determination of full and fair compensation. This is not, however, the case in respect of constructive (regulatory) takings where, as an incident of regulation, owners are substantially deprived of the essential characteristics of ownership: exclusivity, right to transfer and a right to a reasonable use of the property. Takings resulting from over-regulation enacted in good faith are inevitably unintended and thus there is generally no recognition that compensation is necessary or that there need be any process for determining it. In such situations a rebuttable presumption in favour of compensation has arisen. While the taking of actual, physical possession of property or of title to it are clearly recognized as takings, the concept of constructive taking

U.S. Const. amend. V provides, in part, “" nor shall private property be taken for public use, without just compensation."

Canadian Pacific Raihugy Co. :. Vancouver (City) (2004), 237 D.L.R. (4th) 40, 2004 BCCA 192.

A.V. Dicey, Introduction io the Siudy of the Lav' of the Constitution, 3d ed. (Toronto: Vannevar, 1899) at 39. Sec also Authorsom v. (Canada) Anorney General, [2003] 2 S.C.R. 40, 2003 SCC 39 [Authorson], which by expressly negating any claim for payment of past interest owed to individual war veterans on their pensions paid and invested on their behalf by the government, clearly illustrates the indefcasible nature of the principle of parliamentary sovereignty. Less relevant, but equally illustrative of parliamentary sovereignty, the Supreme Court of Canada in Authorson refused to read into the procedural due process provisions of the Canadian Bill of Rights (S.C. 1960, c. 44, reprinted in R.S.C. 1985. App. III) any substantive due process compelling Parliament to actually provide for an adjudicative process before extinguishing property rights without compensation.

Lastly, it is important to note that the general nature of the ownership rights involved in $A u t h o r s o n$ arose out of statutory benelits conlerred by legislation. Such benefits themselves have not consistently been seen as "property" in the U.S. See Pitman v. Chicago Bd. of Education, 64 F.3d 1098 (7th Cir. 1995): (cert. denied) 517 U.S. 571 (1978), where the Court commented: "If a statutory benefit could not be rescinded without the payment of compensation to the beneficiaries, it would be extremely difficult to amend or repeal statutes" (at $11(04-1105$ ). Similar views were expressed in McKinley v. Unired States, 828 I:.Supp. 888 (D.N.M. 1993). Of course in Auhorson, what was at issue was the extinguishment of a right to interest that ought to have accrued. This clearly was property - the extinguishment of ownership of it was quite different than a mere prospective reduction or extinguishment of the statutory benefit itself:

B Being Schedule B to the Comuda Act 1982 (U.K.), 1982, c. 11.

Awhorson, supra note 5, where the Supreme Court of Canada refused to read into the Canadian Bill of Rights protection of procedural due process in respect of deprivation of property any substantive right to compensation. 
arising from excessively onerous regulations or prohibition, being a judicial construct, is necessarily a body of law that is created incrementally and which evolves slowly. Canadian judicial thinking around the issues raised by constructive expropriation is far from fully formed.

The main characteristics ${ }^{8}$ of Canadian constructive takings arising from excess regulation are:

1. there must be a complete deprivation of ownership in the sense of exclusivity, access and use; 9

2. such deprivation must be accompanied by an identifiable consequent acquisition in specie by the regulatory authority or its beneficiary; ${ }^{10}$

3. there is a presumption that fair compensation must be paid when property is so taken, but such presumption may be rebutted on a finding by a court of legislative intent to deny compensation regardless of the onerous effect of the regulation on ownership;" and

4. the regulation affecting the constructive expropriation must be otherwise valid in order to have any takings effect at all, and what is taken must be property. ${ }^{12}$

This article examines regulatory takings claims under art. 1110 of the North American Free Trade Agreement $(N A F T A)^{13}$ and provides an exposition of the law insofar as it has developed in the $N A F T A$ context. It concludes by highlighting the obvious differences between the protection afforded to foreign $N A F T A$ investors in Canada and domestic owners of property when property is constructively taken.

8 For a fuller discussion, see Raymond E. Young. "Canadian Law of Constructive Fxpropriation" (2005) 68 Sask. L. Rev. 345. Also see R.J. Bauman, "Exotic Expropriations, Government Action and Compensation" (1994) S2(4) Advocate (B.C.) 561.

- See British Columbia v. Tener, [1985] I S.C.R. 533 [Tener]; Manitoba Fisheries Lid. v. Canada, [1979] 1 S.C.R. 101 [Manitoba Fisheries]; and Alberta (Minister of Infrastructure) v. Nilsson (2002), 320 A.R. 88, 2002 ABCA 283 at para. 20 [Nilsson], where the Alberta Court of Appeal noted "that the test for $d \varepsilon^{\prime}$ facto expropriation is a complete 'taking' or total extinguishment of rights, without payment of compensation." Despite this blunt assertion in Nilsson, a majority in the Nova Scotia Court of Appeal in Mariner Real Estate Lid. v. Nova Scotia (A.G.) (1999), 178 N.S.R. (2d) 294 [Moriner Real Estole] agreed in obiter that the right to build a summer cottage on a beach-front lot could constitute a taking. despite the fact that family camping or picnicking might still be allowed as recreational uses.

Sec Tener, ibid,; Maniroba Fisheries, ibid.: Nilsson, Bbid., and also Stecer Holdings v. Manisoba (1992). 83 Man. R. (2d) 171 (C.A.) at 177, where the Manitoba Court of Appeal failed to find a taking, stating: "But in my opinion there was no corresponding benefit or acquisition by the Province of Manitoba.... To qualify for compensation there must be an expropriation, if not in name, then in effect. The limitation on usage must be balanced by some corresponding acquisition by the authority." Similarly, a majority in Mariner Real Estate, ibid., did not perceive any need to identify an acquisition in specie where all rights to build a summer cottage on a waterfront lot was denied.

"See Burmah Oil Co. v. LordAdrocate, [1965] A.C. 75 at 156 [Burmah Oil]; Belfast, supra notc I at 523; Manitoba Fisheries, ihid, B.C. Medical Services Association v. British Columbia (1985), 15 D.L.R. (41h) 568 (B.C.C.A.) at 573 [BC.MSA]; and Rock Resources v. British Columbia (2000), 229 D.L. R. (4ih) I15. 2003 BCCA 324 at 152 [Rock Resources] where the court held that mere silence was not sufficient to rebut the presumption and "what is required is clear legislative intention."

12 Governmen of Malaysia v. Selangor Pilot Association, [1978] A.C. 337 (P.C.) [Selangor]; Grape Ban' Limited v. A.G. Bermuda. [2002] I W.L.R. 574, 1999 UKPC 43.

13 North American Free Trade Agreement Between the Government of Canada, the Government of Mexico and the Government of the Unifed States, 17 December 1992, Can. T.S. 1994 No. 2, 32 I.L.M. 289 (entered into force 1 January 1994) [NAFTA]. 


\section{UNITED STATES TAKINGS LAW}

While the focus of this article is a comparison between NAFTA's regime for constructive expropriation and Canadian law, both a short exposition of current American law and of international law in respect of takings will be useful to illustrate NAFTA's affinity to principles applied in international law and the substantial difference between it and the two major common law jurisdictions in North America.

As with both Canada and the U.K., the modern genesis for regulatory takings in the U.S. is Holmes J.'s observations cited in the opening paragraph of this article. In terms of compensation, the U.S. has elevated this principle from a common law presumption to a constitutional entitlement. ${ }^{14}$ In 1978, the U.S. Supreme Court's decision in Penn Central Transportation Corp. v. New York City ${ }^{15}$ commenced a spate of regulatory takings decisions that has extended over 27 years. It remains the seminal and single most important case in U.S. takings jurisprudence. The tests for takings set out in Penn Central are still the tests by which almost all takings claims are judged.

In Penn Central, New York City refused to permit a railway to build office towers over its operating railway station. The station was a protected landmark. The court accepted (and has not as yet changed its mind) that there is no bright line to demarcate a regulation that goes too far, and one that does not. Each case must be decided on its facts, and involves an ad hoc inquiry that engages a three-part balancing test: the economic impact of the regulation on the property owner, ${ }^{16}$ the character of the government action ${ }^{17}$ and the extent to which the regulation interferes with distinct investment-backed expectations. ${ }^{18}$

There are three circumstances in which a taking will not be subject to the Penn Central three-part balancing test: formal expropriation, physical occupation or possession of the property by the government, ${ }^{19}$ and where regulatory restrictions so affect property that no

it See supra note 3.

is 438 U.S. 104 (1978) [Penn Centra].

16 U.S. courts applying Penn Central have rarely found a taking where the diminution in value did not exceed at least 75 percent. See Florida Rock Industries Inc. v. Uniled States, 243 F.3d 555 (U.S. App. 2000) and Lucas v. South Carolina Coastal Council, 505 U.S. 1003 at 1019 (1991) [Lucas], where the U.S. Supreme Court suggested that upwards of 95 percent loss in value might be sufficient.

This test includes an analysis of the public interest, the purposes served by the regulation and their importance. See Tahoe-Sierra Preservation Council v. Tahoe Regienal Planning Agency, 535 U.S. 302 (2002) [Tahoe-Sierra], in the District Court where the purpose of the moratorium was weighed against cconomic impact on the owner. See also Bernardsville Quarn' inc. v. Borough of Bernardsville, 129 N.J. 221 (Sup. Ci. 1992).

"Distinct" is used in this test to mean "highly visible" or imminent as opposed to abstruct or speculative expectations. See Webb's Fabulous Pharmacies v. Beckwith. 449 U.S. 155 at 16I (1980), and Ruckelshaus v. Monsanto, 467 U.S. 986 at 1005 (1984). 
viable use whatsoever can be made of $\mathrm{it}^{20}$ These three situations are referred to as per se takings because the rule applied to them is based on a categorical duty to pay compensation. ${ }^{21}$

\section{Constructive Takings In INTERnational. LAW}

While international arbitral tribunals have often prefaced any views expressed in respect of constructive takings with words of caution and care, they have accepted the principle that regulation (the police power) may have substantial effects tantamount to expropriation:

It is undisputed in this ease that the Govemnent of Iran did not issuc any law or decree... However, it is recognized in intemational law that measures taken by a State can interfere with property rights to such an extent that these rights are rendered so useless that they must be deemed to have been expropriated, even though the State does not purport to have expropriated them and the legal tille to the property formally remains with the original owner. ${ }^{22}$

The oft-cited Third Restatement of Foreign Relations Law of the U.S. is a common entry to discussion of constructive expropriation claims in international law:

Subsection (1) [relating to responsibility for injury from improper takings] applies not only to avowed expropriations in which the government formally takes title to property, but also to other actions of the government that have the effect of "taking" the property, in whole or in large part, outright or in stages ("creeping expropriation"). A state is responsible as for an expropriation of property under Subsection (1) when it subjects alien property to taxation, regulation, or other action that is confiscatory, or that prevents. unreasonably interferes with, or unduly delays, eflective cejoyment of an alien's property or its removal from the state's territory. ${ }^{23}$

Similarly, the Harvard Drafi Comvention on International Responsibility of States for Injuries to the Economic Interests of Aliens, is a frequent citation - in particular art. 10(3)(a):

Lucas, supra note 16. Also sec Tuhoe-Sierra, supra note 17, where at 330 the court noled that the catcgorical rule in Lucas "was limited to the extraordinary circumstances when no productive or economically beneficial use of land is permitted. '... The emphasis on the word 'no' in the text of the opinion. was in effect, reiterated in a footnote explaining that the categorical rule would not apply [to anything less than a total loss]."

"I Is noteworthy that Mariner Real Estate, supra note 9, is akin to Lacas, ibid. Lucas was cited and followed at least by the trial court judge. Both Mariner Real Estate and Lucas arise out of beach and dune preservation regulations that have the effect of severely restricting or prohibiting construction of summer cottages and houses on beachfront lots. Two appellate judges on a panel of three in Muriner agreed in obiter that a complete extinguishment of a right to construct even a modest cottage could constitute a taking. Mariner is, however, really a "ripeness" case as it was not clear that new applications to build cottages designed to be more sensitive to dune preservation would not ultimately be issued, the propenty owners had to make further applications before the majority would agree that a taking had occurred. See discussion of Mariner Real Estate in Young. supra note 7.

$\because \quad$ Starrell Housing Corp. v. Iran ( 1987$)$. (1991) 85 I.L.R. 349 (Iran-Uniled States Claims Tribunal), Final Award at both 390 (reasons of Lagergren) and 398 (reasons of lloltzmann) [Starrett]. Lt is an important caveat and is generally recognized that the scope and jurisdiction of Iran-United States Claims Tribunals extended beyond takings and included simple interference in relation to property rights. However, here the Tribunal's claaracterization of constructive taking is not extraordinary in the context of aceepted principles of intemational law. 
A "taking of propeny" includes not only an outright taking of property but also any such unreasonable interference with the use, enjoyment, or disposal of property as to justify an inference that the owner thereof will not be able to use, enjoy, or dispose of the propery within a reasonable period of time after the inception of such interference. ${ }^{24}$

The ways in which an international constructive taking may occur are many. Some of the well-recognized ones have been noted as:

Economic excreises of public power, regardless if they actually serve in particular instances as the functional equivalents of deprivations for which compensation traditionally has been expected, can be conveniently. although not rigidly, grouped according to the techniques governments commonly use to affect not title to, but (a) participation in, (b) use of, and (c) benefit or yield from wealth processes and values. Compared to diplomatic, ideological, and military excrcises of public power, they provoke, as earlier stated, by far the greatest number of "constructive taking" / "creeping expropriation" claims. Falling into the first ("participation in") subcategory have been, for example, so-called Stale administration measures, the creation of public and private monopolies, the granting of exclusive concessions, and the non-renewal of previously authorized licenses and charters. Falling into the second ("use of") subeategory have been, inter alia, restrictions upon the entry of capital and labor. wage and price controls, distribution and sales prohibitions. the "freezing" or "blocking" of assets, land-use zoning, and the imposition of "servitudes." And falling into the third ("benefit or yield from") subcalcgory have been such other familiar measures as taxation (in diverse forms) and monetary revaluation. As might be expected, "constructive takings" have been most often determined when these kinds of "regulations" have operated, singly or in combination, so as to span or embrace all three of the above subcategorics. ${ }^{25}$

There are many risks for foreign investors in strange lands and most of these lie at the investor's doorstep. In relation to foreign investment, what international law protects against is loss from governmental action or conduct that so substantially impairs ownership rights that it can be said to be clear that those rights have been taken away, or so reduced that it can be characterized as a deprivation of ownership. Not every political risk that destroys an investment is a taking. For example, in Starrett, ${ }^{26}$ the Tribunal found no compensable loss or taking as a result of severe civil disruption and physical interference arising from a revolution, but subsequently did find a taking when the revolutionary government enacted laws wresting control (but technically not ownership) over the investments from the shareholders:

The succinet language of this act makes it clear llat the appointment of [a temporary manager] in accordance with its provisions deprived the sharcholders of their right to manage... As a result of these measures the Claimants could no longer exercise their rights to manage and were deprived ... of effective use and control of it. $^{27}$ 
While temporary measures may effect a taking, the public purpose and transitory nature of them may militate against any such finding. Whether core elements of ownership of exclusive possession, right to transfer, control and right to reasonable use and enjoyment are substantially interfered with is fact sensitive, and the degree and extent to which the complained of measures interfere with an investment is essential to any finding of a constructive taking. ${ }^{28} \mathrm{tt}$ is clear that the interference must be significant and substantial. However, the ascertainable single test eludes international jurists as it does domestic courts in both Canada and the U.S.9

\section{CONSTRUing NaFTa ARTICLE 1110}

The model from which the wording of NAFTA's art. 1110 has emerged is based on the evolution of preferred language used by western industrial nations in the latter half of the twentieth century in innumerable bilateral investment treaties (BITS). The U.S. and other western European nations rejected the CALVO Doctrine, which favoured the view that the law of the host state should govern domestic as well as foreign investors. BITS became popular even among states that espoused the CALVO Doctrine because even though they neutralized the CALVO doctrine, their result was to effectively promote western (particularly U.S.) investment. As of 2000 , some 1500 BITS have been documented, many of which contain language similar, if not identical, to NAFTA's art. $1110 .^{30}$ The current language found in NAFTA's art. 1110, coupled with the novelty of investor-state (rather than state-to-state) arbitration is coming under some attack both in Canada and in the U.S. as leading to results requiring compensation never intended and quite different from U.S. domestic law. ${ }^{31}$

: $\quad$ For a comprehensive review of takings in customary intemational law see: G.C. Christie, "What Constitules a Taking of Property Under Intemational Law" (1962) 38 Brit. Y.B. Int'I L. 307; Weston. supra note 25; Rudolf Dolzer, "Indirect Expropriations: New Developments?" (2002) 11 N.Y.U. Envtl. L.J. 64; George H. Aldrich, "What Constitutes a Compensable Taking of Property? The Decisions of the Iran-United States Claims Tribunal" (1994) 88 Am. J. Int'l L. 585.

24 Weston, ibid. at 121. where the author concludes: "The multidimensional "consiructive taking' problem simply cannot be handled satisfactorily by unidimensional methods." Also see Daniel M. Price, "Chapter 11 - Privale Party vs. Government. Investor-State Dispute Settlement: Frankenstein or Safety Valve?" (2000) 26 Can-U.S. L.J. 107, where the author notes:

The negotiators tried for some time to consider putting in a line in the lext that would distinguish between legitimate regulation on the one hand. bona fide and nondiscriminatory. and a taking on the other hand.

We quickly gave up that enterprise. If the U.S. Supreme Court could not do it in over 150 years, it was unlikely that we were going to do it in a matter of weeks with one exception.

Vicki Been \& Joel C. Beauvais, "The Global Fifth Amendment? NAFTA's Investment Protections and the Misguided Quest for an International 'Regulatory Takings' Doctrine” (2003) 78 N.Y.U. L. Rev. 30.

lbid. The authors not only question the necessity for uny protection in international law for regulatory taking. but also raise significant concerns about the differences apparent between U.S. constitutional treatment of regulatory takings. and the approach taken by NAFTA tribunals. In particular. Been and Bcauvais note that NAPTA itself intentionally broadens the nature of compensable property interests, and extends an entillement to compensation beyond the effect of legislative and administrative actions to include judicial actions and conduct. The authors also express concern that the concept of ripeness, which plays an important part in U.S. takings law, has been ignored by NAFTA tribunals. The latter concern may be premature given that NAFTA tribunals have rejected all but one takings claim, and in that one (Metalclad Corporation v. United Mexican States (2000), [2002] 119 I.L.R. 615 (International Centre for Settlement of Investment Disputes) [Metalclad]), ripeness was not an issue. 
International arbitral awards and case law arising out of expropriation claims often refer to proper and improper takings. A common refrain is:

There is, of course, authority, in international judicial and arbitral decisions, in the expressions of national governments, and among commentalors for the view that a taking is improper under international law if it is not for a public purpose, is discriminatory, or is without provision for prompt, adequate, and effective compensation. $^{32}$

In fact, with the additional conditions of due process and minimum standard of treatment, art. $1110(1)$ of NAFTA appears to be worded to reflect the view that in order to be lawful, an expropriation must meet the general tests identified in many of the international arbitral decisions:

I. No party may directly or indirectly nationalize or expropriatc an investment of an investor of another Party in its territory or take a measure tantamount to nationalization or expropriation of such an investment, except:

(a) for a public purpose:

(b) on a non-discriminalory basis;

(c) in accordance with due process of law and Article $1105(1)$; and

(d) on payment of compensation in accordance with paragraphs 2 through $6 .^{33}$

Despite its conventional appearance, it is surprising that art. $1110(1)$ is framed as a prohibition. It is not, and could not be, a prohibition. For all practical purposes, NAFTA tribunals may only award full and fair compensation when a taking occurs, and may only compensate in accordance with art. 1110 . No injunctive, declaratory or prerogative relief is available and no punitive awards may be made. While a NAFTA tribunal may order restitution of property, the host state may opt, at its discretion, to substitute compensation. ${ }^{34}$ In any event, in respect of constructive takings another factor militates against any restitution of property $-i t$ is difficult in constructive takings where title remains in the investor to identify how restitution would be affected, except by repeal in whole or sufficient part of the regulation giving effect to the taking. Such order could not be made by a NAFTA tribunal. In this context, it does not, despite the wording of art. 1110, make any sense to treat the prohibitory form as having any effective meaning. If a state expropriates either formally or by excess of regulation in breach of either or all of art. $1110(1)$ subsections (a), (b) or (c), but satisfies subsection (d) by paying full and fair compensation, there is no basis for a claim under art. 1110 , nor may there be any possible sanction under art. 1110 for breaching any of the meritorious conduct that art. $1110(1)(a),(b)$ and (c) seems to demand. ${ }^{35}$

Banco Nacional de Cuba v. Sabbatino, 376 U.S. 398 at 429 (1964) [footnotes omitted]. NAFTA, supra note 13, c. 11, art. $1110(1)$.

Ibid., art. $1135(1)$.

This raises the issuc of whether the eompensation provisions of art. 1110 are a code and thus a limitation of tribunal jurisdiction, or whether a tribunal may treat breaches of ant. 1 I 10(a) through (c) as making any expropriation unlawful by nature and thus award reparation damages. For general discussion of unlawful takings and reparation awards, see Samrat Ganguly, "The Investor-State Dispute Mechanism (ISDM) and a Sovereign's Power to Protect Public Health"(1999) 38 Colum. J. Transnat'] L. 113; Casc" Concerning the Factory at Chorzow (Germany v. Poland) (1928) P.C.J.J. (Ser. A) No. 17. In addition see $N A F T A$, ibid, c. 11 , art. $1135(3)$ prohibiting punitive damages. 
Conversely, it is equally clear that if a regulatory measure has an impact that rises to the level of a substantial, if not total, deprivation of an investment, adherence by the host state to the principles enunciated in art. $1110(1)(a),(b)$ and (c) will not avoid the obligation to pay compensation under art. $1110(1)$ (d). As the Tribunal in Pope and Talbot Inc. v. Canada ${ }^{36}$ observed in considering Canada's submission that all non-discriminatory regulation is beyond the reach of $N A F T A$ rules regarding expropriation:

While the exercise of police powers must be analysed with special care, the Tribunal believes that Canada's formulation goes too far. Regulations can indeed be exercised in a way that would constitute creeping expropriation....

Indecd, much creeping expropriation could be conducted by regulation, and a blanket exception for regulatory measures would create a gaping loophole in international protections against expropriation. ${ }^{37}$

In S.D. Myers Inc. v. Canada, ${ }^{38}$ Schwartz giving separate reasons (although not contentious on this point) comments:

Concerns about Article 1110 are especially great because it requires compensation for governmental conduct that is entirely lawful and reusonable under both national and international standards. An expropriation or nationalization does not have to be unlawful or improper in any sense to trigger a right of compensation under Article $11100^{39}$

It seems obvious also, notwithstanding the wording of art. 1110 , that where a regulation does not rise to the level of a taking in terms of substantial deprivation of essential characteristics of ownership of an investment, but governmental conduct brenches some or all of the apparent conditions required by art. $1110(1)($ a) through (c), then despite such conduct, no compensation is required. Article 1110 provides no relief whatsoever when no taking has occurred. It would seem in such cases that if any relief is available, it would have to be found either elsewhere in c. 11, or under domestic law.

The above analysis of art. 1110 is very much like that advanced by the Tribunal in Marvin Feldman Karpa v. Mexico." There the Tribunal commented that the key issue was whether Mexico's actions constituted a taking. In respect of the remainder of art. 1110 , the Tribunal observed:

The Article 1110 language is of such generality as to be difficult to apply in specific cases. In the Tribunal's view, the essential determination is whether the actions of the Mexican government constitute an expropriation or nationalization, or are valid governmental activity. If there is no expropriatory action, factors

(2001), [2002] 122 1.L.R. 293 (Arbitration Tribunal), A ward on the Merits of Phase 2 ['ope and Talbor]. Ibid. at para. 99; see also Marvin Roy Feldman Karpa v. United Mexican States (2002). [2003] 18 I.C.S.I.D. Review 488 (International Centre for Settlement of Investment Disputes), Final Award at para. $110[K a r p a]$, where the majority noted that "[n]o one can seriously question that in some circumstances govermment regulatory activity can be a violation of Aricle $1110 . "$

(2000), [2002] 121 I.L.R. 73 (NAFTA Arbitration Tribunal under the UNCITRAL. Rules), Partial Award [S.D. Myers].

lbid. at para. 205.

Supra note 37. 
a-d are of limited relevance, except to the extent that they have helped to differentiate between governmental acts that are expropriation and those that are not, or are parallel to violations of NAFTA Articles 11112 to 1 105. If there is a finding of expropriation, compensation is required, even if the taking is for a public purpose, non-discriminatory and in accordance with due process of law and Article $1105(1){ }^{41}$

Whether there is in law a "taking" is a threshold issue and, as the NAFTA awards will show, such a finding turns primarily (if not overwhelmingly) upon the substantive effect of regulatory measures on the investment, and not on intent ${ }^{12}$ or lack of public purpose, or whether the measure was non-discriminatory or arrived at through due process. Indeed, a lawful, non-discriminatory regulation enacted in good faith for a public purpose and having a severe effect on both domestic and NAFTA party foreign investors may attract compensation for the latter, regardless of the result under domestic law.

\section{INVESTMENT}

Article 1110 protects investments. The definition of this term is intentionally extremely broad. ${ }^{43}$ It certainly includes real property and chattels forming part of the investment, as well as both tangible and intangible property of the investment. In addition, this definition includes any entity organized under applicable law, whether or not for profit, as well as stocks, bonds, debt security, enterprise income, right to profit, concessions, franchises, charters and licence contracts. ${ }^{\text {H4 }}$ There are certain limited exclusions applicable to c. 11 generally, and several specific to art. $1110^{45}$

Compounding the expansiveness of the nature of "an investment," art. 1110 provides that c. I1's scope and coverage applies to measures "relating to" (inter alia) investments. Thus in S.D. Myers, the Tribunal found that a ban on the export of PCBs "related to" S.D. Myers" enterprise of exporting PCBs for remediation at its American facility and, as such, border access was an essential element of the investment. ${ }^{46}$ Similarly, in Pope and Talbot, the Tribunal found that fee quota controls on export of wood, which limited access by the investor to the American market, constituted interference (although not rising to the level of a taking) with an investment interest that the Tribunal referred to as a property interest: ${ }^{47}$

Ibid. at para. 98 [emphasis in original].

42 Katharina A. Byme, "Regutatory Expropriation and State Intent" (2000) 38 Can. Y.B. Int'I L. 89. suggests that a finding of objective intent ought to be the determinative test of taking in intemational law. The reasoning is, however, circular given its reliance on cases where intent was found, but only as a necessary consequence of a prior finding that the effect of the regulation was to take. Sec Ulster Transport Authority v. James Brown \& Sons, [1953] N.1. 79 (C.A.), as well as Lord Salmon's dissent in Selangor, supra note 12, where the principle that Parliament must intend the necessary effects of its acts gave rise to finding of intent, but only after an effects-based finding of a de facto taking. For a view that liability for taking in intemational law is not affected by intent or lack thereof see Aldrich, supra note 28.

4 Prict, supra note 29.

4NAlTA, stupra note 13, c. 11 , art. 1139.

4. Bid., art. $1110(7)$.

th S.D. Myers, supra nolte 38 at para. 234.

" Pope and Talbot, supra note 36 at para. 96, where the Tribunal labels "access to the U.S. market" as a "propenty interest subject to protection under Article $1110 . "$ 
While Canada suggests that the ability to sell softwood lumber from British Columbia to the US is an abstraction, it is, in fact, a very important part of the "business" of the Investment. Interference with that business would necessarily have an adverse effect on the property that the Investor has acquired in Canada, which of course, constitutes the Investment. Whilc Canada's focus on the "aceess to the U.S. market" may reflects only the Investor's own terminology, that terminology should not mask the fact that the true interests at stake are the Investment's asset base, the value of which is largely dependent on its export business. The Tribunal concludes that the Investor properly asserts that Canada has taken measures affecting its "investment," as that term is defined in Article 1139 and used in Article $1110 .{ }^{48}$

While not a NAFTA decision, a Tribunal's award in Southern Pacific Properties (Middle East) Lid. v. Arab Republic of Egypr ${ }^{9}$ is instructive because contractual rights form part of what constitutes an investment under art. 1110 of NAFTA. The Tribunal in Southern Pacific Properties found that a presidential decree totally cancelling the development of two tourist complexes by a joint venture company owned in part by Egypt and in part by a foreign investor (Southern Pacific Properties) constituted a taking of property despite Southern Pacific having been left with its shares in the joint venture, and despite no transfer of the contractual rights to any other party. ${ }^{50}$

\section{MeAsures}

A key element of art. 1110 relating to constructive takings is found in the words "take a measure tantamount to ... expropriation." With reference to the meaning of "tantamount to," the Tribunals in Pope and Talbot" and in S.D. Myers ${ }^{52}$ found that "tantamount" means equivalent to, and thus did not extend the established expropriatory test of substantial interference or deprivation. The term "measure" is defined in NAFTA quite broadly as including "any law, regulation, procedure, requirement or practice."33

In Eihyl Corp. v. Canada, ${ }^{34}$ Canada attempled to limit the scope of the term, and argued that "no legislative action short of a statute that has passed both the House of Commons and the Senate and has received Royal Assent constitutes a 'measure' subject to arbitration under Chapter 11." In commenting on this position, the Tribunal pointedly noted Canada's own briefing notes (to its own government) explained "measure" very broadly:

The term "measure" is a non-exhaustive definition of the ways in which governments impose discipline in their respective jurisdictions."

Jbid. at para. 98.

(1992), [1997] 106 I.L.R. 501 (International Centre for the Settlement of Investment Disputes. Arbitration Tribunal). Final Award [Sowhern Pacific Properties].

A valid contract is certainly property in the U.S. pursuant to the Fifth Amendment. In Linch: U.S., 292 U.S. 571 (1933), a cancellation of rights under the contract can be a compensable taking.

Supra note 36 at 337.

Supra note 38 al 123.

NAFTA, supra note 13, c. 2, art. 201(1).

(1998), [2002] 122 I.L.R. 250 (NAFTA Arbitration Tribunal under the UNCITRAL Rules), Award on Jurisdiction $[E t h y]$.

Ibid. at para. 66, referring to "Statement on Implementation of the North American Free Trade Agreement" Can. Gaz. Part IC(1), Jan. 1994. 
The Tribunal later observed that "[c]learly something other than a 'law,' even something in the nature of a 'practice,' which may not even amount to a legal stricture, may qualify."

\section{NAFTA/CONSTRUCTIVE TAKINGS}

Unlike formal and intentional expropriations in respect of which the only real issues under art. 1110 of NAFTA are likely to be those bearing directly on tribunal jurisdiction and on valuation (including the identity and nature of the investment and the date of valuation), takings claims based on substantive deprivation of use, enjoyment, access and control must be examined, weighed and considered in the factual matrix surrounding the claim to see whether the degree, extent or severity of the loss and deprivation constitutes a taking for which compensation is payable.

The five NAFTA decisions to date in which a claim under art. 1110 has been considered do not advance any more fully formed or clearly defined indicators to constructive takings than is apparent in either the Third Restatement or the Harvard Draft: ${ }^{37}$

Recognizing direct expropriation is relatively casy: governmental authorities take over a mine or factory, depriving the investor of all meaningful benefits of ownership and control. However, it is much less clear when govermmental action that interferes with broadly-defined property rights - an "investment" under NAFTA, Article 1139 - crosses the line from valid regulation to a compensable taking, and it is fair to say that no one has come up with a fully satisfactory means of drawing this line. ${ }^{58}$

All of the current awards do, however, display a recognition and acceptance of the view that bona fide (as to public purpose) regulatory measures may result in impacts on investment that rise to the level of a taking "tantamount to expropriation." Except in Metalclad (the most egregious of the fact situations), claims under art. 1110 have not been made out. In some part, this is because art. 1110 itself must be construed in the context of $\mathrm{c} .11$ as a whole, and other provisions of $c$. 11 often provide, on the same facts, sufficient remedies to obviate the necessity of finding a taking under art. 1110 . It is, however, also fair to say that tribunals have displayed very real caution in endorsing a successful invocation of art. $1110 .{ }^{59}$ Unless that line has been so clearly passed (in which case there being still no need to locate it with any precision), tribunals have not found a taking. ${ }^{6 / 7}$ It seems clear, too, that despite "popular fears," the bar to finding a substantial deprivation is set quite high. $\ln$ S.D. Myers both the majority and the dissent made the point that excess of regulation, rising to a taking will be

S6 Ethyl, ibid.

37 For a discussion on the various possible tests to determine whether a constructive taking has occurred in international law, see Weston, supra note 25; Christic, supra note 28; Dolzer, supra note 28. Karpo, supra note 37 at para. 100.

This is clear from the fact that of the five full considerations of art. 1110 to date, all but one have been rejected. The only one accepted was a complete sterilization of a multi-million dollar capital investment. Also see reasons of Schwartz in S.D. Myers, supra note 38, where he expresses concern over the sensitivity of art. 1110.

Metalclad, supra note 31. See also Charles H. Brower, “Investor-State Disputes under NAFTA: A Talc of Fear and Equilibrium" (2001) 29 Pepp. L. Rev. 43, where the author comments that NAFTA tribunals have adhered to the prevailing norm that regulatory measures may considerably affect foreign investment without rising to the level of a taking, and that investors under NAFTA face great difficulty in establishing construetive takings claims. 
uncommon, the majority stating: "Regulatory conduct by public authorities is unlikely to be the subject of legitimate complaint under Article 1110 of the NAFTA, although the Tribunal does not rule out that possibility. ${ }^{\infty 1}$

In considering the factors to be taken into account in determining whether "measures tantamount to an expropriation" are in play, the decisions overwhelmingly rely on effect or impact analysis based on the factual context of cach situation. In this regard, while lacking the structured balancing undertaken by American courts arising out of application of the Penn Central tests, the ad hoc factual analysis is an important commonality.

In Azinian v. United Mexican States, ${ }^{62}$ the first in the art. 1110 chronology, the Tribunal's award turned on a finding that a contract that was invalid under domestic law was no contract at all, and could not thus be the subject of an expropriation. The Mexican courts had held that the concession contract at issue was invalid as a result of the claimant's misrepresentations. Because the claimant did not assert that the domestic decision of the Mexican courts was itself a breach of art. 1110, the Tribunal did not need to go further. While not decided by the Tribunal, Mexico had also raised the defence that a contract repudiated for failure to perform could not be said to have been expropriated. The Tribunal had evidence before it of the claimant's breach of the contract, and it seems apparent from the tenor of the reasons for the award that the Tribunal would have agreed with this proposition as well.

On the issue of whether repudiation of a contract is per se a taking (had it in fact been wrongly repudiated by the Mexican municipality), the Tribunal demanded an analysis based on substance and not form. The claimant sought to cast the annulment of the contract not as a mere breach, but as confiscatory of the contractual rights forming the investment. The Tribunal's approach was to distinguish between breaches of contract that were confiscatory, and those that were not:

The problem is that the Claimants' fundamental complaint is that they are the victims of a breach of the Concession Contract. NAFTA does not, however, allow investors to seek international arbitration for mere contractual breaches. Indeed, NAFTA cannot possibly be read to create such a regime, which would have clevated a multitude of ordinary transactions with public authorities into potential intemational disputes. ${ }^{63}$

In respect of the claimants' argument that there was a confiscatory breach, the Tribunal disagreed, noting that "labeling" was no substitute for analysis:

The words, "confiscatory," "destroy contractual rights as an asset", or "repudiation" may serve as a way to describe breaches which are to be treated as extraordinary, and therefore as acts of expropriation, but they

S.D. Miers, supra note 38 at para. 281 . See also Schwarty in separate reasons where he notes at para. 207: "There may be some cases where a measure that is presented as a regulation must, in law and justice, be treated as a nationalization or expropriation for the purposses of Article 1110 . That said, I can also state that in the vast run of cases, regulatory conduct by public authorities is not remotely the subject of legitimate complaints under Article 11 10." 
certainly do not ind icate on what basis the critical distinction between expropriation and an ordinary breach of contraet is to be made. ${ }^{64}$

As the contract was invalid, it was not necessary for the Tribunal to go on to consider whether the annulment by the Mexican authorities was proper because of the claimant's nonperformance, or whether it was merely a breach of contract that did not rise to the level of a taking.

In Pope and Talbot, the claimant argued that the phrase "measure tantamount to expropriation" had the effect of lowering the bar for what constitutes an expropriation from substantial deprivation to the level of that of any measure merely interfering with an investment. On the latter basis the claimant asserted that, although such interference need not be severe enough to constitute a substantial or total deprivation, it was nevertheless caught by art. 1110 . The Tribunal rejected that notion. ${ }^{65}$ The claim in Pope and Talbot was based on the Canadian government's imposition of an export fee on softwood lumber going from some provinces to the U.S. While the evidence was that the fee as it affected the claimant diminished its profits (although it was still profitable), the Tribunal had no hesitation in arriving at the conclusion that the effects of this measure were not tantamount (equal) to expropriation. In examining the evidence, the Tribunal found that there was no loss of control of the enterprise or of the investment, and that the reduction of profits per se in this case could not rise to the level of a taking. The Tribunal cited both the Harvard Draft and the Third Restatement for the proposition that the claimant had not been deprived of effective enjoyment or control, or an ability to dispose of the property of the enterprise, to a degree that could be viewed as confiscatory.

The only tribunal award in which a claimant has yet been successful in showing a taking under art. 1110 is Metalclad Corporation v. United Mexican States. ${ }^{67}$ After appeal to the Supreme Court of British Columbia, ${ }^{68}$ the sole ground for finding a taking was a Gubernatorial Ecological Decree creating an ecological reserve area for cacti. Such a decree had the effect as found by the Tribunal of forever barring the commencement of operation of a newly constructed and fully approved facility for hazardous waste disposal.$^{69}$ Metalclad claimed some $\$ 20$ million in out-of-pocket costs to acquire the land and build the facility, and was ultimately awarded and received about $\$ 16$ million. ${ }^{70}$ Although constructed and ready, the plant never had an opportunity to become operational. In respect of the test for constructive takings, the Tribunal noted the phrase "a measure tantamount to ... expropriation" and stated:

Thus, expropriation under NAFTA includes not only open, deliberate and acknowledged takings of property, such as outright seizure or formal or obligatory transfer of title in favor of the host State, but also covert or incidental interference with the use of property which has the effect of depriving the owner, in whole or in

Pope and Tulbot, supra note 36 at para. 105.

Ihid. at para. 102.

Sipra note 31.

United Mexican States v. Metalclud Corporation. [2002] 119 l.L.R. 646 (B.C.S.C.) [Mfetalclad. 2002].

Metalclad, supra note 31 at para. 109.

Ibid. at para. 131. 
significant part, of the use or reasonably to be expected economic benefit of property even if not necessarily to the obvious benefit of the host State. ${ }^{71}$

The Tribunal clearly applied an effects analysis in respect of the Ecological Decree, and was not concerned with purpose:

The Tribunal need not decide or consider the molivation or intent of the adoption of the Ecological Decree... However, the Tribunal considers that the implementation of the Ecological Decree would, in and of itself, constitute an act tantamount to expropriation. ${ }^{72}$

In this, the Tribunal was quite correct on the facts. The cactus reserve certainly served a public purpose, and whether it was a trivial or weighty public purpose is irrelevant on the facts. As earlier tribunals had noted, non-discriminatory, lawful (having a valid public purpose) regulation may effect a taking. Indeed, one certainly expects formal expropriations to be in the public interest, and the fact that they are, and the fact that the public interest at stake is significant and important, in no way militates against there being a de jure and de facto expropriation followed by a duty to compensate. ${ }^{73}$ In addition, given the complete deprivation of the investment, intent was equally irrelevant. Whether the Decree was intended as a colourable device to take under an environmental guise, or a bona fide expression of environmental concern, the result was "a take" all the same. Melalclad does not stand alone; it simply confirms that constructive takings are governed by an effect-based test that requires substantial, if not complete, deprivation of an investment. In this regard, on the facts as found by the Tribunal, the result in Metalclad does not deviate from the parameters set by other awards in international law, or under art. 1110 of NAFTA.

On appeal to the Supreme Court of British Columbia, the Court commented on the Tribunal's effect-based test:

[T] he Tribunal held that expropriation under the NAFTA includes covert or incidental interference with the use of property which has the effect of depriving the owner, in whole or in significant part, of the use or reasonably-to-be-expected economic benefit of property. This definition is sufficiently broad to include a legitimate re-zoning of property by a municipality or other zoning authority. However, the definition of expropriation is a question of law with which this Court is not entilled to interfere under the International $C A A^{74}$

On its face, the Court's comments appear alarming. However, given the facts from which they arise, and on which their persuasive authority is dependant, they are not apt. Certainly in all American municipal jurisdictions north of Mexico, rights in respect of a newly

Ibid. at para. 103.

Jbid. at para. III.

In respect of even the most urgent and important of public interests, L.cord Pearce's comments in Burmoh Oil, supra note 11 at 156 are apt: "It is right that in time of war the Government ... should have the power to take ... property ... for the safety of the realm. But the express practice of Parliament for 250 years and more has clearly shown that there is no concurrent necessity to deprive the subject of compensation."

Metalclad, 2002, supra note 68 at para. 99. 
constructed industrial facility (having all necessary approvals as found by the Tribunal) would have vested. ${ }^{76}$ In Canada, changes in land use regulations affected by subsequent rezoning would not preclude either the commencement of a use, or its continued operation where there had been a clear commitment to use evidenced by lawful construction. ${ }^{77}$

S.D. Myers ${ }^{7 x}$ involved a Canadian company owned by Americans incorporated to export PCBs from Canada to a related company's remediation facility in the U.S. The related American company was successful in having a U.S. prohibition against importation of PCBs lifted in respect of its facility for a two-year period. Canada, which at the time had no regulations prohibiting export of PCBs, promptly prohibited such exports by Order of Council. After about 15 months, Canada relented. However, as a result of a judicial ruling in the U.S., the U.S. border was subsequently again closed to the importation of PCB waste.

The Tribunal held in favor of S.D. Myers' claims under art. 1102 (national treatment) because of discrimination against a U.S. investor, and under art. 1105 for failing to provide the minimum standard of treatment in accordance with international law. However, it denied any award for takings under art. 1110.

The majority of the panel played with the general concepts of regulatory taking like Goldilocks with porridge - nothing was ruled out, "hot," "cold" or "just right!" In respect of regulatory measures, the Tribunal noted that "regulatory conduct ... is unlikely to be the subject of legitimate complaint under Article 1110 of the NAFTA, although the Tribunal does not rule out that possibility." ${ }^{\text {"79 }}$ It also commented that "[a]n expropriation usually amounts to a lasting removal [of economic rights] although ... in some contexts and circumstances, it would be appropriate to view a deprivation as amounting to an expropriation even if it were partial or temporary." 80

Metalciad, supra note 31 at paras. 105-106, where the Tribunal held that the exclusive authority for permitting a hazardous waste landfill resided with the Mexican federal government and that the municipality (if it had authority at all in respect of building permits) acted outside its authority in relusing to issue the building permit. Given the publicity and volume of informed and uninformed commentary on the casc, it is important to nute that whether the very experienced judicial members of the tribunal got the real facts wrong is irrelevant in the assessment of art. 1110 because the case (if it is a precedent for anything) only extends to subsequent situations where the facts as found are equally egregious.

Even if the Tribunal's finding that Metalclad had all the permits it required in law was wrong and a building permit was required, its incidental finding that such permits had been wrongly denied would not in Canada support govemmental action to demolish or remove the facility. Any such intent would have been rebuffed and mandamus would lie to compel issuance of the necessary permit. Vesting would not be jeopardized by a highly technical defect such as the absence of a permit when the cause of such defect was a wrong of the permit issuer. only if the legislature of British Columbia enacted a statute to probibit the continuation of an existing land use and expressly provided that no compensation should be paid would a foreign investor protected by NAFTA be advantaged over a domestic user of land in identical circumstances. 
Continuing to cover all the bases, the majority of the Tribunal also paid cursory lip service to the idea that "purpose and effect" of governmental measures ought to be examined..$^{81}$ In contrast, however, in determining that there was no taking, the Tribunal made no reference to "purpose" (or improper purpose given its parallel finding of discrimination under art. 1102)..$^{82}$ Rather, the Tribunal focused on effect only, and concluded correctly that the export ban did not affect a transfer of property, and that it was temporary in nature and of no direct benefit to others. ${ }^{83}$

The last effect cited by the Tribunal (no direct benefit to others) echoes an earlier general comment by the majority that:

In general, the term "expropriation" carries with it the connotation of a "taking" by a governmental-type authority of a person's "propeny" with a view to transferring ownership of that property to another person, usually the authority that exercised its de jure or de facto power to do the "taking." "ks

In a similar vein, the minority member of the panel also noted that takings

tend to deprive the owner and to enrich - by a corresponding amount - the public authority or the third party to whom the property is given. ${ }^{\text {ss }}$

Ihid.

82 The idea that the nature of the public purpose ought to be a fackor weighed together with effect is attractive to those having concern for the protection of health, safety. the environment and other public interest issues to which the police power is so often remedially or protectively directed. Sce Dolzer, supra note 28 , where the author, acknowledging the current primacy of effects-based analysis, suggests that a balancing test, according some weight to public purpose, might be appropriate. Other commentators have gone further and proposed wording for a complete "carve out" from art. 1110 of all measures having a valid public purpose that adhere to due process and that are non-discriminatory (H. Mann \& K. Molkte, "NAFTA's Chapter II and the Environment: Addressing the International Impacts of the Investor-State Process on the Environment" (1999), online: International Institute for Sustainable Development < $<w w$.iisd.org/pdf/nafta/pdß>). In a similar vein, H. Mann \& J. A. Soloway in "Untangling the Expropriation and Regulation Relationship: Is there a Way fonward?" online: Department of Foreign Aflairs and International Trade <www.dfait-maeci.ge.ca/tna-nac/documents/untangle-e.pdf $>$ note the current reliance on an effects-based test, but appear to diverge in their conclusions as to what extent a finding that a regulatory measure is bona fide ought to play in respect of liability under c. 11 , art. 1110. In contrast, Daniel Price, "Some Observations on Chapter 11 of NAFTA" (2000) 23 Hastings Int'l \& Comp. L. Rev. 421 argues that providing blanket immunity for areas such as health or the environment would vitiate one of the purposes of art. 1110 , which is lo equitably spread the costs of significant public interest measures. In a similar vein, see the comments of Lord Pearee in Burmah Oil, supva note II at 143.

That the weight of the public purpose at issue should always raise the bar before a taking may be found was rejected by the common law in A.G. v. De Keyser's Royal Hotel, [1920] A.C. 508, where Lord Parmoor noted at 569: "Assuming that there is a public necessity to take possession of" land for administrative purposes in connection with public delence, there can be no reason why this necessity should be urged as an answer to a claim for compensation." See also Lord Moulton at 553.

In examining the staled reasons, the following are expressly stated: the closure of the border was temporary and the delay did have an economic eflect: since it was temporary such effect is better adklressed in relation to arts. 1102 and 1105 of NAFTA; Canada received no benefit from the measure; and there was no transfer of property to any other person. See S.D. Myers, supra note 38 at para. 284. 
This approach to a taking, requiring an acquisition, certainly reflects the current Canadian position and it is perhaps no accident that two of the three panel members were Canadians. The existence of an acquisition in international law is certainly a common fact found in expropriations by the state, in nationalization and in the cancelling of concessions and their transfer to third parties. It seems the better view that the Tribunal was only observing that an acquisition was a tendency, but not an essential element of a taking. The minority member's views on acquisition were certainly framed this way, although transfer is obviously an important indicator that would point to a finding of a taking. ${ }^{86}$

On the issue of "acquisition" the Metalclad Tribunal did not see any need for there to be a finding of transfer or acquisition. It was sufficient that the investment had been wholly sterilized, and as the Tribunal noted in respect of takings generally, the deprivation need not be "to the obvious benefit of the host state." ${ }^{87}$ It is not apparent at all that any acquisition in specie is required before a regulatory taking may be found in international law. There was no transfer or acquisition of any rights to the state or any third party in Southern Pacific Properties, ${ }^{88}$ where the contracts were simply cancelled and the projects abandoned. Similarly in Tippetts, Abbott, McCarthy, Siratton v. TAMS-AFFA Consulting Engineers of Iran, ${ }^{\text {ky }}$ the Tribunal expressly denied any necessity for acquisition, asserting it to be a general principle of international law:

\footnotetext{
The claimant is entilled under international law and general principles of law to compensation for the full value of the property of which it was deprived. The Tribunal prefers the term "deprivation" to the term "laking" although they are largely synonymous, because the latter may be understood to imply that the Govemment las acquired something of valuc, which is not required. ${ }^{90}$
}

In the end, the majority in S.D. Myers held that the export ban was a temporary measure that delayed the benefits flowing from the exercise of economic rights. However, it was not a deprivation of ownership. Such delay damages as there were, were appropriately subject to an award under art. 1102 of NAFTA. ${ }^{91}$ The minority member concurred in not finding a taking. His reasons were that the export ban was temporary; there was no clear transfer of benefit to the government or to third parties; and it is proper to consider art. 1110 in the context of $\mathrm{c} .11$ as a whole, and in this regard there was an adequate alternate remedy under other heads of the claim in respect of breaches of other articles of NAFTA. Consistent with other tribunal decisions considering art. 1110, neither the majority nor the minority put any real weight on the purpose of the measure in the context of art. 1110 .

The most recent NAFTA award to date considering art. 1110 in relation to the merits of a claim is the award in Karpa. ${ }^{92}$ At issue in the claim was a denial of tax rebates by Mexico

Ibid. at para 221: "Another difliculty here is that there was not a clear transfer of wealth from S.D. Myers to cither the government or to its Canadian competitors. Denying S.D. Myers the ability to carry out its business did not necessarily shift that same business to its Canadian competitors." Meialclad, supra note 31 at para. 103.

Supra note 49.

Award No. 141-7-2, 6 Iran-U.S. C.T.R. 219 (1984).

Ibid. at 225.

S.D. Myers, supra note 38 at paras. 283-84, and separate reasons of Schwartz at para. 222.

Supra note 37. 
to a cigarette re-seller (not a producer) on export of cigarettes from Mexico. The facts were complex; however, a key finding was that rebates were not available to the claimant because under Mexican law (although not necessarily enforced consistently) rebates required production of invoices from suppliers. The claimant could not obtain such invoices from its suppliers who, for their own reasons, would not provide them.

The Tribunal noted that there were no significant breaches of the conduct required by art. 1110 (a) to (c) and, even if there had been, they would not elevate the case to one of a taking in the face of a failure of the effects of the regulation to rise to a level of substantial deprivation. The Tribunal characterized the rebate denial as a business problem (legitimate under Mexican law) in respect of a "gray market" in cigarettes. Most tellingly, the Tribunal noted that there was no loss of control over the enterprise, and that the investment still profited by exporting many other products besides cigarettes. While the cigarette trade may have become uneconomic, there was no deprivation of ownership of the investment that could be said to rise to the level of a taking. The Tribunal in Karpa also echoes a strong refrain often heard from the U.S. Supreme Court in relation to the application of the threepart Penn Central test to takings claims. ${ }^{93}$

Ultimately, decisions as to when regulatory action becomes compensable under Article 1110 and similar provisions in other agreements appear to be made based on the facts of specific cases. This Tribunal must necessarily take the same approach. ${ }^{94}$

Again, in respect of the issue of acquisition, the Tribunal in Karpa would seem not to have considered it a prerequisite to a finding of a taking, commenting that "creeping expropriation' [includes] ... a state seeking 'to achieve the same result [as in an outright taking] by taxation and regulatory measures designed to make continued operation of a project uneconomical so that it is abandoned." "9s The reference to "abandonment" is clearly suggestive of some recognition of a dispersed public benefit arising from the cessation of the investment activity rather than from any transfer to, or acquisition of, continuing rights by some public authority or even a third party.

\section{COMParison of CaNADA'S AND NAFTA'S CONSTRUCTIVE TAKINGS LAW}

Loss of sovereignty has been a recurring theme of critics of the NAFTA regime. Coincidentally, some commentators have described international trade agrecments like NAFTA as akin to constitutional documents. ${ }^{96}$ In this regard, it is significant that the doctrine of Parliamentary sovereignty, which plays such a defining role in relation to the property

Penn Central, supra note 15 and Anthony Palazzolo v: Rhode Island, 533 U.S. 606 (2001), where takings analyses are characterized as being "essentially ad hoc, factual inquiries."

4 Ibid. at para. 101.

* David Schneiderman, "NAFTA's Takings Rule: American Constitutionalism Comes 1o Canada"(1996) 46 U.T.L.J. 499 at 514-15. While it is true that c. II of NAFTA is like the United States' Fifth Amendment in the sense that it creates a self-executing right to compensation for the taking of property (a right that is not apparent in the Constitution Act. 1982), it is not fair to say that the law of regulatory takings under NAFTA bears any relationship to the three-part balancing test favoured (for all but per se takings) by American courts. Sec also Penn Ceniral, supra note 15. 
rights of ordinary Canadians, is rendered irrelevant by NAFTA in relation to the rights of foreign NAFTA party investors in Canada. Without breaching its international obligations under the treaty, or alternatively negotiating amendments to NAFTA, Parliament cannot override or negate its duty to compensate foreign investors under $c .11$, art. 1110 when measures are found by an international tribunal (appointed pursuant to the investor-state dispute provisions) to have an effect tantamount to expropriation. The practical result of this status is to elevate art. 1110 above domestic common law, and transfer the evolution and development of the jurisprudence away from domestic courts and into the hands of international jurists.

Similarly, the "presumption" in favour of compensation that is so prominent and problematic in Canadian constructive takings law is wholly unnecessary in respect of NAFTA claims. Article 1110, like the just compensation clause of the Fifth Amendment to the American Constitution, is self-executing and expressly provides for compensation to be paid. Investors do not need to urge a Tribunal under NAFTA to find a clear legislative intention to compensate, it is the rule. ${ }^{47}$

Unlike the law in either Canada or the U.S., there is no need for the concept of regulatory takings to be judicially constructed by extension of rules related to formal expropriation. Article 1110 of NAFTA contains a direct reference to "measures tantamount to expropriation" and thus the concept of regulatory taking is expressly recognized. Just as significantly, the broad definition of the word "measures" in the NAFTA context extends far beyond regulation and includes custom, practice and also laws, orders and decisions of the host state's judiciary. ${ }^{98}$ It has also been suggested that NAFTA can be breached when domestic courts fulfilling a review function under NAFTA do not show sufficient curial deference to the original Tribunal's decision. ${ }^{99}$

97 In Canada, while the government inevitably makes provision for compensation and its determination when formally expropriating, constructive expropriation is always unintended (when the regulations are enacted in good faith), and thus there is often no provision for compensation or for a process to determine it. In such circumstunces, the presumption in favour of compensation comes into play. To what extent legislative intention must be clear to rebut the presumption remains a somewhat open question. Whether silence is sufficient to rebut the presumption or whether express words are necessary (in uddition to intention gleaned from surrounding circumstances) still requires judicial clarification. Sce BCMSA and Rock Resources, stupra note 11.

98 It was accepted in Azinian, supra note 62 at paras. 99-103, that the conduct of domestic courts can cause a host state to breach NAFTA. The Tribunal observed that undue delay, or where justice was "seriously inadequate," or where there was a clear and malicious misapplication of the law, a claim might be made. In Loew'en Group Inc. v. U.S.A. (2002), International Centre for Settlement of Investment Disputes, online: $<w w w$.state.gov/documents/organization/22094.pdi, the current claim relates to court conduct in Mississippi. Similarly in Mondev International Lu. v. U.S.A. (2002), Intemational Centre for Seltlement of Investment Dispules, online: <www.statc.gov/documents/organization/14442.pdf $>$ the claim related to the conduct of the Massachusetts courts, and there the Tribunal at para. 127 eited Elellronica Sicula S.p.A. (ELSI) (United States of America v. Ilaly), [1989] 1.C.J. Rep. 15 lor a test of "a wilful disregard of due process of law ... which shocks, or at least surprises, a sense ol judicial propricty."

4) See Charles H. Brower, "Investor-State Dispules under NAFTA: The Empire Strikes Back" (2001) 40 Colum. J. Transnat'l L. 43, and also Charles H. Brower, "Beware the Jabberwock: A Reply to Mr. Thomas" (2002) 40 Colum. J. Transnat'l L. 465. 
In Canadian law, regulatory takings claims are necessarily restricted to takings of property - or more accurately, core ownership rights pertaining to property. While Canadian courts have taken a broad and liberal approach to what constitutes property, the scope of that concept is still firmly anchored within the bounds of what the common law would treat as property - that is, real property, personal property and other things of value in respect of which an owner may claim exclusive possession, right to transfer and transmit, access and some reasonable use, at least to the extent of the ownership right. ${ }^{100}$

The truly expansive definitions of the terms "investment" and "investor" under NAFTA extend the reach of its protections far beyond that found in Canadian law in relation to protection of property interests and in relation to those who have standing to assert a taking of a property. ${ }^{101}$ The protection under NAFTA is a protection of "investment," and that concept includes almost all property at law, ${ }^{102}$ and even related abstractions such as "market share" and "access to market."103

NAFTA shares with the law in both Canada and the U.S. the problem that there is no bright line demarcating regulation that takes, and regulation that does not take. ${ }^{104}$ In addition, as with domestic courts in the U.S. and Canada, NAFTA tribunals have not shown any significant interest in formulating a test that weighs purpose and intent against impact and effect on property or on investment. The primary, if not sole, factor considered by NAFTA tribunals has been the effect of the impugned measures on the investment, and on the ownership rights of the investor in respect of the investment. The issues are examined in a fact-based inquiry specific to the case at hand. If measures substantially deprive the investor of use or the ability to operate (prohibition, denial of access to the border or markets), or deprive the investor of ownership or control, enjoyment, access to or right to dispose of the investment, a taking may be found. The fact that the impugned measure was enacted or implemented for a bona fide public purpose, as is the case in domestic law, would not be a determinative factor in finding a right to compensation.

Not only have NAFTA tribunals not been overly concerned with the public purpose or value of the measures complained of as giving rise to compensation, NAFTA tribunals have no jurisdiction to judge the validity of the host state's measures, or to invalidate or otherwise set aside measures taken by a host state. Thus, unlike domestic courts, which ought to avoid

100 See Manitoba Fisheries, supra note 9, where "goodwill" was considered property capable of being construetively taken. Also sce Tener, supra note 9 where Crown-granted mineral claims were similarly considered property. But see Sanders v. British Columbia (Milk Board) (1991), 77 D.L.R. (4th) 603 (B.C.C.A.) where a quota assigned by the Milk Board was held to be a mere licence to produce and sell but was not property per se. In that case the Court, quoting Cory J.A. in Nat. Trus/ Co. v. Bouckhut (1987), 43 D.L.R. (4th) 543 at 550-53, staled at 611: "The notion of "property' imports the right to exclude others from the enjoyment of, interference with or appropriation of a specific legal right. This is distinct from a revocable licence. which simply enables a person to do lawfully what he could not othervise do." In S.D. Myers, supra note 38, the claimants were individuals owning shares in a foreign corporation that owned the Canadian company aflected by the "measures."

102 There are exclusions set out in NAFTA: see art. 1139 and also Annexes I to IV.

103 Sec S.D. Myers, supra note $\mathbf{3 8}$ and Pope and Talbot, supro note $\mathbf{3 6}$.

104 In Belfast, supra note I at 519, Viscount Simuonds had to settle for Holmes J.'s very general observation in Pennsylvania Coal, supra note 2 at 415 , that: "The general rule at least is, that while property may be regulated to a certain extent. if regulation goes too far it will be recognized as a taking." 
the takings issue altogether if the measure is itself invalid for any reason, NAFTA tribunals are compelled under art. 1110 to determine only if the measure gives rise to such substantial deprivation that compensation ought to be paid.

Lastly, it is a significant difference that NAFTA tribunals have not required any acquisition or constructive acquisition in specie as a consequence of and an essential element of a regulatory taking. It is sufficient if the deprivation itself is substantial enough to vitiate essential characteristics of ownership. Measures tantamount to expropriation under art. 1110 require compensation even if their effect is not one of transfer of the investment, but is merely an augmentation of public benefit generally.

It is clear in the end that the NAFTA regime does establish a scheme for compensation in respect of regulatory takings that is substantially different, far broader and much more protective than similar law applying to domestic investors in Canada. In large part, it may well be that the major differences apparent between the NAFTA takings regime and those of Canada, Mexico and the U.S., have a great deal to do with the fact that all three domestic systems are so different. In addition, because the CALVO Doctrine espoused by Mexico presented a major disincentive to Canada-U.S. investment in Mexico, Mexico would gain no advantage by insisting upon its incorporation into NAFTA. One might assume that Canada and the U.S. each would have accepted their own system; however, compromise reflective of the then-current development of the language in use in innumerable BITS avoided any attempt at an amalgam of Canadian and American domestic law. 